\title{
STRENGTH ANALYSIS OF GLUED-IN STEEL RODS WITH DIFFERENT LOCATIONS IN CLT PANELS CROSS SECTION
}

\author{
Bidakov Andrii ${ }^{1 *}$, Raspopov Ieugeniy ${ }^{2}$, Pustovoitova Oksana ${ }^{3}$, Strashko Bogdan ${ }^{4}$ \\ ${ }^{1}$ O.M. Beketov National University of Urban Economy in Kharkiv https://orcid.org/0000-0001-6394-2247 \\ ${ }^{2}$ O.M. Beketov National University of Urban Economy in Kharkiv https://orcid.org/0000-0002-5084-5533 \\ ${ }^{3}$ O.M. Beketov National University of Urban Economy in Kharkiv https://orcid.org/0000-0003-4078-4834 \\ ${ }^{4}$ O.M. Beketov National University of Urban Economy in Kharkiv https://orcid.org/0000-0003-0336-8276 \\ *Corresponding author E-mail: bidakov@kname.edu.ua
}

New types of wood based building materials to which the CLT refers require an accurate evaluation of the strength of various types of connections. CLT panels connections with glued-in steel rods are of interest due to the possibility of creating quickmounted and rigid joints in the factory. Since the CLT have the structure of the perpendicular orientated boards in adjacent layers, the strength and behaviour of the pasted rods is difficult to predict. The purpose of this study was to establish the strength of the glued-in rods by pull-pull tests with different locations relative to the boards layers in the cross-section of the CLT panel. Diameter of all considered steel rods was smaller than thick of timber planks $30 \mathrm{~mm}$ in 5-lyers CLT specimens without gaps and stress relieves. Anchored length of rods in all specimens was $100 \mathrm{~mm}$ by using two component epoxy adhesive system.

Keywords: cross laminated timber, CLT, connection, glued-in steel rods, joint, prefabricated panels, strength by pull-pull tests

\section{АНАЛІЗ МІЦНОСТІ ВКЛЕСНИХ СТЕРЖНІВ З РІЗНИМИ ТОЧКАМИ РОЗТАШУВАННЯ У ПОПЕРЕЧНОМУ ПЕРЕРІЗІ ПКД ПАНЕЛЕЙ}

\author{
Бідаков А.М. ${ }^{1 *}$, Распопов С.А. ${ }^{2}$, Пустовойтова О.М. ${ }^{3}$, Страшко Б.О. ${ }^{4}$ \\ 1,2,3,4 Харківський національний університет міського господарства ім О.М. Бекетова \\ *Адреса для листування E-mail: bidakov@kname.edu.ua
}

\begin{abstract}
Нові типи дерев'яних будівельних матеріалів, до яких відносяться CLT або ПКД панелі, вимагають точної оцінки міцності різних типів з'єднань. З'єднання ПКД панелей на вклеєних стержнях представляють інтерес через можливість створення на виробництві швидко монтуючихся і жорстких з'єднань. Оскільки ПКД має структуру перпендикулярно орієнтованих дощок у сусідніх шарах, міцність та поведінку наклеєних стрижнів важко передбачити. Метою цього дослідження було встановити міцність вклеєних стрижнів за допомогою випробувань на висмикування стрижнів розташованих у різних точках відносно шарів дощок у поперечному перерізі ПКД панелі. Діаметр усіх розглянутих сталевих стержнів був меншим за товщину дощок 3 деревини яка складала 30 мм у 5-шарових зразках CLT без щілин між дошками і компенсаційних пропилів у дошках для зняття напруги. Глибина вклеювання стрижнів у всіх зразках становила 100 мм та використовувалась двокомпонентна епоксидна система. Для стрижнів використовували сталеві шпильки з метричною різьбою М10, М12 та М14 класу міцності 5.8. Метод випробування проводився відповідно до вимог стандарту EN 1382:1999. Навантаження прикладалось 3 постійною швидкістю від 0,5 до 1,5 мм/хв до відмови або руйнування з'єднання. При випробуваннях вклеєних стержнів велику увагу слід приділяти не тільки несучій здатності, але й поведінці при руйнуванні. Для визначення міцності на висмикування вклеєних стержнів, встановлених у боковій поверхні плит CLT, було випробувано 75 зразків. Всього було розглянуто 5 можливих точок встановлення вклеєних стержнів у поперечному перерізі ПКД або CLT панелі, які можуть мати різну міцність. Це перш за все стрижні встановлені у повздовжні і поперечні дошки поперечного перерізу ПКД панелі, стрижні встановлені на межі повздовжньої та поперечної дошки і на межі двох повздовжніх дошок, а також розглядався варіант розташування стержня на межі двох повздовжніх і однієї поперечної дошки.
\end{abstract}

Ключові слова: вклеєні стержні, збірні панелі, з'єднання, поперечна клеєна деревина, ПКД, міцність при висмикуванні, стик 


\section{Introduction}

Glued-in steel rods are very effective type of rigid and semi-rigid joints in GLT elements of different constructions and allow produce structural elements with high level of prefabrication for fast and reliable installation of timber buildings. Positive experience of using gluedin steel rods during large period in timber constructions in Eastern Europe praxis seems effective in joints of cross laminated timber (CLT) panels. In this paper showed the results of pull-pull tests of glued-in steel rods installed in edge face of CLT panels in different possible variations. Also was proposed calculation model and type of joint were it can be used in CLT buildings (Fig.1) for connecting of wall and floor panels or two wall panels.

\section{Review of the research sources and publications}

Analysis of the glued-in rods strength by pulling, depending position in the cross-section, is the same as described in paper [1] of prof. H. J. Blass (2007) where the positions of axially loaded self-tapping screws were varied.

\section{Definition of unsolved aspects of the problem}

The strength of glued-in rods as a rule depends not only on the length of the gluing of the rod and its diameter, but also on the orientation to the grain in the specimens. In CLT panels an interesting case of the arrangement of the rods is the variant on the boundary of two adjacent parallel and perpendicular boards because of the different shear strength of timber along and across the grain. For example, in the tests of glued-in rods in the LVL, the destruction of the cores was observed with the ovalization of the wood near the rod. This is logical and can be explained by the different values of the shear strength by acting force parallel to the layers of veneer and perpendicular to the layers of veneer.

Proposed joint of CLT panels with GiR as well as «XRAD system» produced by Rothoblaas allow increase the level of prefabrication, greater efficiency and reduced times by mounting. In the installation process of this joint can be used for lifting CLT panels and ensure comfortable connecting of panels from the inside of the building. For connecting two wall panels and one floor panel envisaged gluing-in of rods in floor panel. Onesided semicircular apertures in the places of joining the panels allow to slightly reduce the thermal conductivity of the panel. Optimization of considered joint is obviously necessary, especially taking into account the group effect of glued-in rods.

\section{Problem statement}

The aim of the research was to develop proposals for calculating of load carrying capacity of joints with glued-in steel rods in CLT panels by taking into account the position or rod in cross section of CLT panel.. Only axial loaded glued-in steel rods installed in different parts of panels cross section was tested by pull-pull tests and described in this paper. Also withdrawal capacity of glued-in steel single rods in CLT are need for calculation for reinforcement different parts of panels and connections.
Interest to this type of connection in CLT panels occurred in a few papers. Some test results of withdrawal capacity of GIR in CLT elements are published in the STSM Report of B. Azinovic [2], G. Traetta (2007) [4], and in Master thesis of M. Andersen and M. Høier $[3]$.
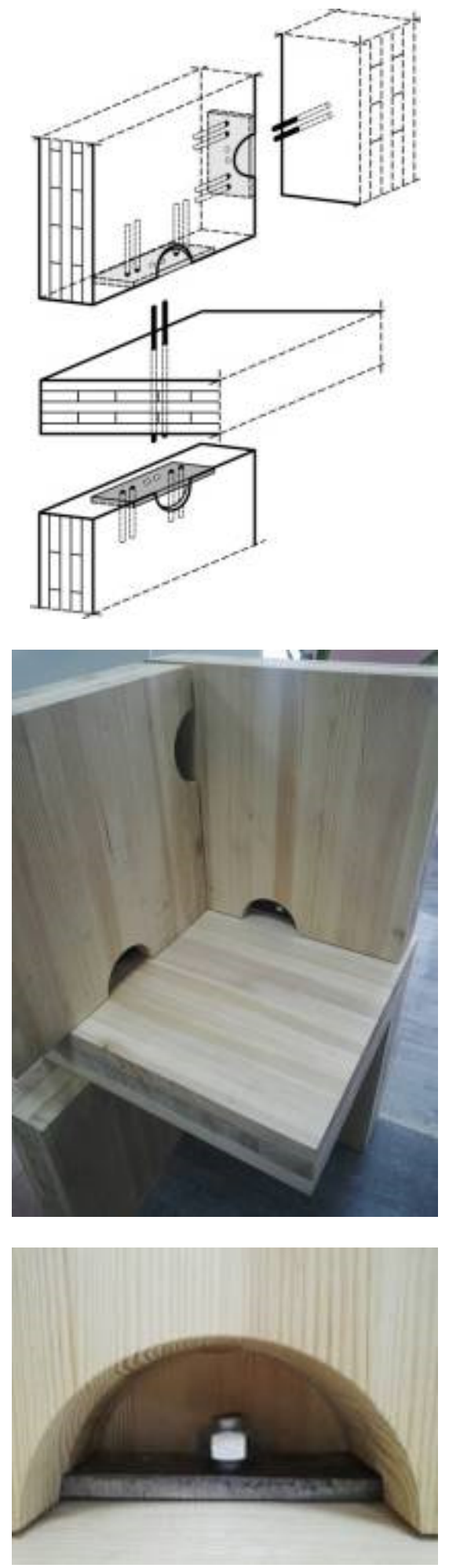

Figure 1 - Possible case prefabricated joint of CLT panels with glued-in steel rods 


\section{Basic material and results}

\section{Materials and methods}

The present research work is considered the influence of glued-in rod (GiR) localization in edge of CLT panels on the value of maximal strength of withdrawal capacity. Diameter of all considered steel rods was smaller than thick of timber planks $30 \mathrm{~mm}$ in 5-lyers CLT specimens without gaps and stress relieves. Anchored length of rods in all specimens was $100 \mathrm{~mm}$ by using two component epoxy adhesive system. The moisture content of the timber was about $12 \%$. The test set-up and the location of GiR are shown on figure 2, where (1) - parallel to the grain in one board; (2) - on the boundary of two parallel and one perpendicular boards; (3) - on the boundary of two parallel boards; (4) - on the boundary of one parallel and one perpendicular boards; (5) - perpendicular to the grain in one board. Differences between specimens were in positions of glued-in rods and diameters of rods, see table 1 .

a)

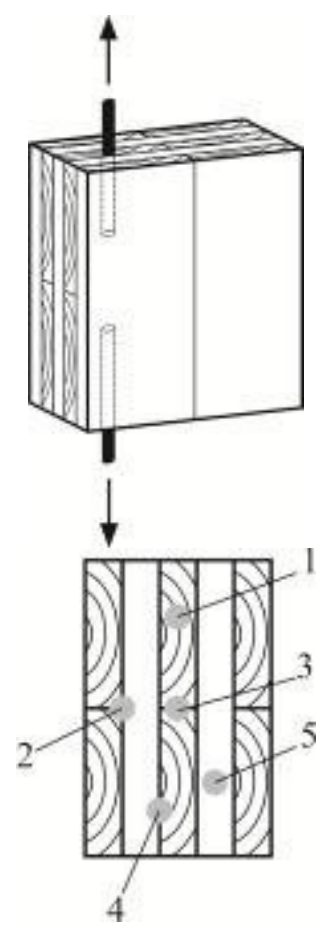

Figure 2 - Schemas:

$\mathrm{a}$ - test set-up; $\mathrm{b}$ - locations of glued-in steel rods in the tested specimens.

Table 1 - Test program

\begin{tabular}{|c|c|c|c|c|c|}
\hline $\begin{array}{l}\text { Test } \\
\text { series }\end{array}$ & 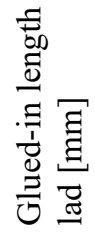 & 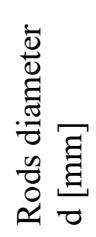 & 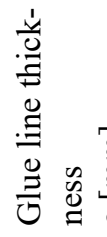 & 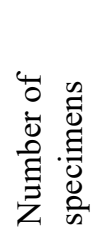 & 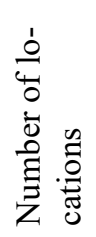 \\
\hline GiR-10 & 100 & 10 & 2 & 25 & $1-5$ \\
\hline GiR-12 & 100 & 12 & 2 & 25 & $1-5$ \\
\hline GiR-14 & 100 & 14 & 2 & 25 & $1-5$ \\
\hline
\end{tabular}

The purpose of the tests was to estimate the load carrying capacity of single GiR. The rods use were threaded steel bars with metric threads M10, M12 and M14 in strength grade 5.8. Test method was according to standard EN 1382:1999 [5]. The load was applied at a constant rate between 0.5 and $1.5 \mathrm{~mm} / \mathrm{min}$ until failure. By tests great attention should be given not only for load capacity, but also to the behaviour of joints.

To determine the withdrawal strength of GiR installed in edge face of CLT plates 75 specimens were tested. In Table 1 show testing program and details of test series. In each location was tested 5 specimens. As shown on Fig.2-b) was considered all possible cases of rods installing which could influence on obtained results. Obviously very interesting seems results of rods located on the bonding lines of two adjacent cross orientated boards.

During the tests was controlled displacement by measuring devices and symmetry of glued-in rods in two planes as shown on figure 3 .

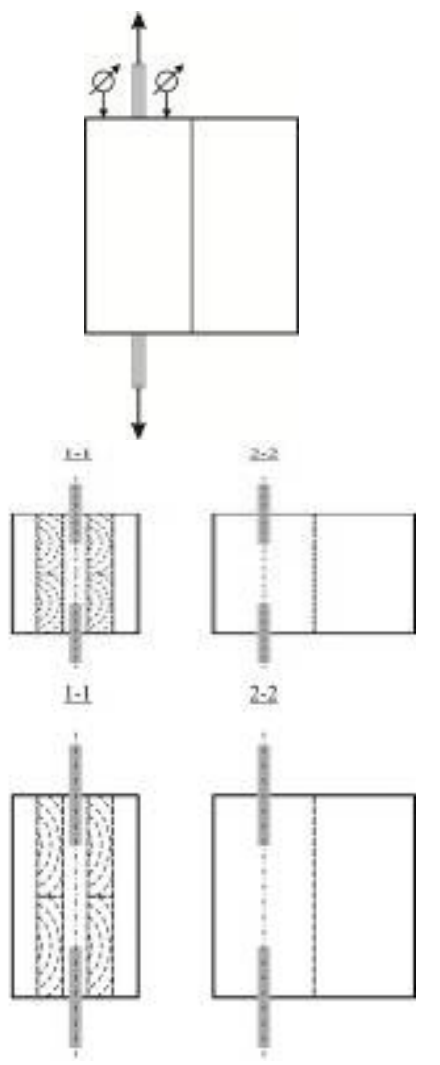

\section{Figure 3 - Location of measuring devices} and symmetry control of glued-in rods

Test results and discussion. The experimental data obtained for CLT have been compared with predictive equations from three references. First is simplified calculation model [6-9] for axial loading which could be summarized as:

$$
R_{a x, k}=\pi \cdot d \cdot l \cdot f_{v, k},
$$

where $R_{a x, k}$ - characteristic pull-out capacity;

$l$ - anchorage length;

$d$ - diameter;

$f_{v, k}-$ shear strength parameter. 
The correlation between test results and predicted values which based on models proposed in DIN 1052 and Russian standard (CП 64.13330.2017) [10] for GiR was analysed as second and third references according to equation (2) and (3)

$$
R_{a x, d}=\pi \cdot d \cdot l_{a d} \cdot f_{k 1, d},
$$

where $R_{a x, d}$ - design axial resistance;

$l_{a d}$ - effective anchorage length;

$d$ - nominal diameter of rod;

$f_{k l, d}-$ characteristic value of bond line strength

$$
T=R_{c \kappa} \cdot \pi \cdot d_{1} \cdot l_{p} \cdot k_{c},
$$

where $T$-design axial pull-out or pierce capacity; $R_{c \kappa}$ - shear design resistance;

$R-4 \mathrm{MPa}$ timber design pull-out resistance or pierce of rod;

$l_{p}$ - design length, $\mathrm{m}$;

$k_{c}=1,2-0,02 \cdot 1 \mathrm{p} / \mathrm{d}$ coefficient which takes into account uneven shear stress distribution in dependency of the anchorage length of rod.

Since in some cases of tested glued-in rods in the CLT panels, the rods were located in the boards perpendicular to the grain. In European practice designers are using the same equations for rods set perpendicular to the grain, or are referring to Widmann et al [12] where the pull-out strength is estimated as follows

$$
F_{\text {ax,mean }}=0.045 \cdot\left(\pi \cdot d_{h} \cdot l_{a d}\right)^{0.8},
$$

where $d_{h}$ - diameter of drill hole in $\mathrm{mm}$.

In accordance to Russian standard [10] the design equation for rods glued-in perpendicular to the grain considered as case of rods glued-in at an angle to the grain as follows

$$
T=R \cdot \pi \cdot d_{1} \cdot l_{p} \cdot k_{c} \cdot k_{\sigma} \cdot m_{d} \leq F_{a} \cdot R_{a},
$$

where $k_{\sigma}=1-0,001 \cdot \sigma$ coefficient which depends on the sign of normal stresses along the grain in the place of rods installation;

$\sigma-$ maximal tension stresses, MPa;

$m_{d}=1,12-0,1 \mathrm{~d}$ coefficient which takes into account dependency of design resistance from rod diameter;

$F_{a}$ - cross section of rod, $\mathrm{m}^{2}$;

$R_{a}$ - design resistance of rod material, $\mathrm{MPa}$.

Typical failure modes that occurred were shear failure along the rod in the adhesive layer, shear failure along the rod in the interface between the adhesive and the surrounding timber, shear failure along the rod in the surrounding timber. Figure 4 shows failure mode of tested specimens. Failure was reaching the shear strength.

Figure 5 show the test results for the GiR diameters 10,12 and $14 \mathrm{~mm}$ depending from installation place of in CLT edge face. It is obvious that the load-carrying capacity increases with increasing of rods diameter, as mentioned above in equation (1).

The increase in deformations when pulling out rods installed across the grain are more intense than for rods installed along the grain, as was noted earlier and described in paper prof E. Serrano [11]. Load-defor- mation curves for rods glued on the border of the longitudinal and transverse boards had intermediate shapes of the curves. Results of the test to study the influence of the rod position in edge surface of CLT panel by pull-pull tests for three different rods diameters are shown in table 2.

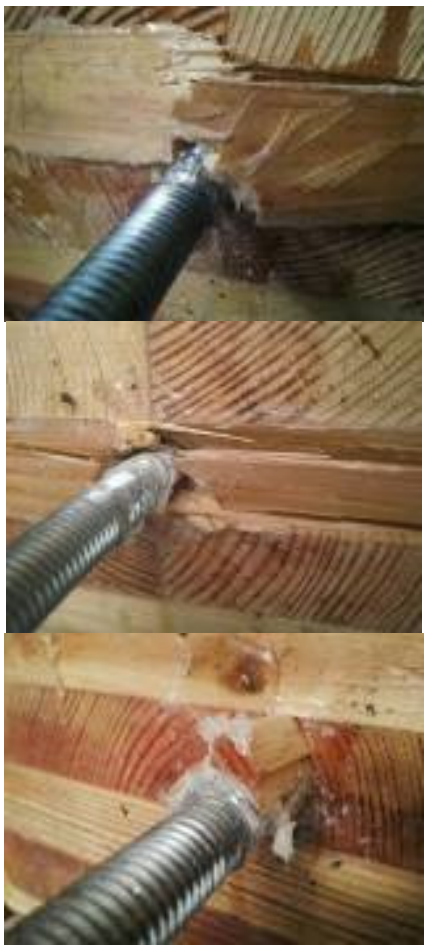

Figure 4 - Failure mode of some tested specimens
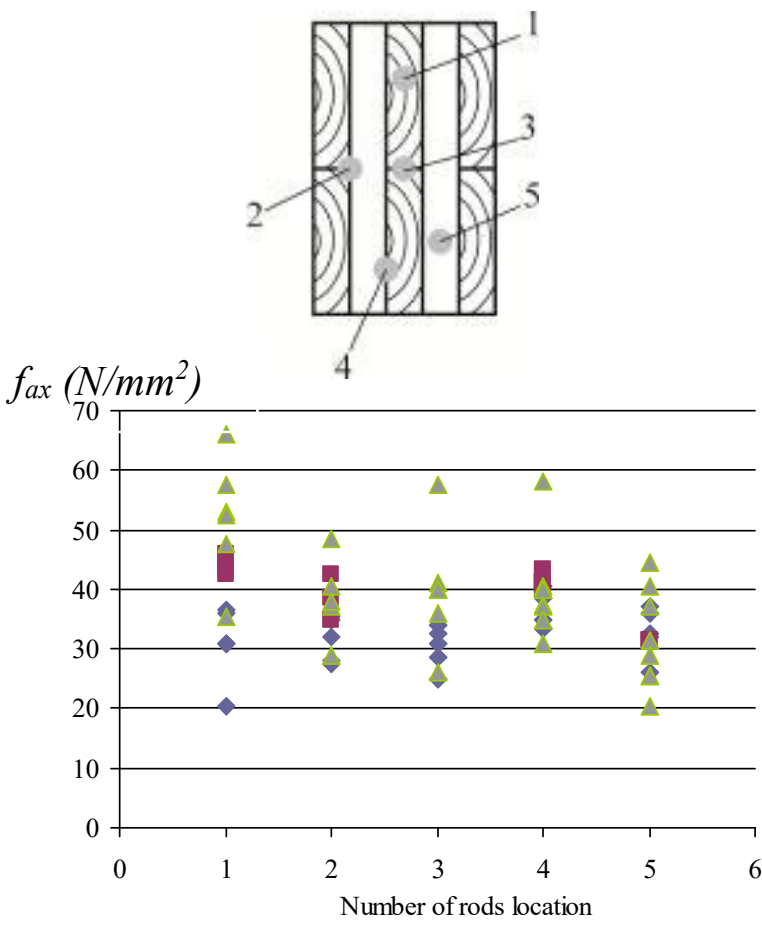

$\checkmark$ diameter $10 \mathrm{~mm} \quad$ diameter $12 \mathrm{~mm} \triangle$ diameter $14 \mathrm{~mm}$

Figure 5 - Test results for different rods diameters by different places of installation 
Table 2 - Test results

\begin{tabular}{|c|c|c|c|c|c|}
\hline $\begin{array}{l}\text { Test } \\
\text { series }\end{array}$ & 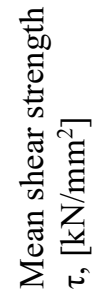 & 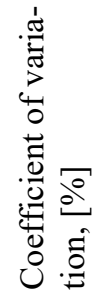 & 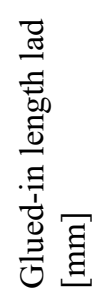 & 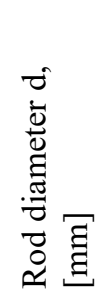 & 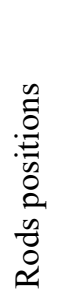 \\
\hline GiR-10-1 & 8,62 & 13 & 100 & 10 & \multirow{3}{*}{1} \\
\hline GiR-12-1 & 7,17 & 11,5 & 100 & 12 & \\
\hline GiR-14-1 & 6,32 & 26 & 100 & 14 & \\
\hline GiR-10-2 & 8,38 & 11,9 & 100 & 10 & \multirow{3}{*}{2} \\
\hline GiR-12-2 & 8,8 & 9,7 & 100 & 12 & \\
\hline GiR-14-2 & 7,68 & 18,2 & 100 & 14 & \\
\hline GiR-10-3 & 7,85 & 11,9 & 100 & 10 & \multirow{3}{*}{3} \\
\hline GiR-12-3 & 7,51 & 13,7 & 100 & 12 & \\
\hline GiR-14-3 & 7,98 & 25,4 & 100 & 14 & \\
\hline GiR-10-4 & 9,69 & 8,7 & 100 & 10 & \multirow{3}{*}{4} \\
\hline GiR-12-4 & 9,42 & 3,1 & 100 & 12 & \\
\hline GiR-14-4 & 7,93 & 21,6 & 100 & 14 & \\
\hline GiR-10-5 & 8,23 & 20,8 & 100 & 10 & \multirow{3}{*}{5} \\
\hline GiR-12-5 & 10,07 & 3,5 & 100 & 12 & \\
\hline GiR-14-5 & 10,35 & 19,6 & 100 & 14 & \\
\hline
\end{tabular}

Figure 6 shows the influence of rods diameter on withdrawal strength, where lines «din» and «ru» are predicted values according to German standard DIN 1052 and Russian standard CП 64.13330:2017 for roads glued-in along the grain. Test results for rods glued-in perpendicular to the grain versus predicted values obtained according Russian standard and equation (4) proposed by R. Widmann shown on figure 7. As a rule, the test results are slightly higher than the expected strength values of GiR, because in the calculation formulas (1) and (3) the characteristic value of the strength by shear is used.

Also by shear testing of specimens, the resulting strength value corresponds to a flat stress state. When pulling out the GiR installed along the grain is observed volume destruction and it is necessary to consider the volumetric stress state. For example, by tests of GiR in LVL was found ovalization of the fracture area, which is explained by different shear strength along the grain due to the layered structure of the material. This aspect is taken into account and used in the calculations according to our proposed method. For GiR located on the border of the longitudinal and transverse boards in CLT, a non-uniform stress state also arises depending on the part of the contact area of the GiR with one of the board surfaces.

For CLT panels with gaps and stress relieves, the installation of GIR is also possible. In the drilled hole, which coincides with the gap, in the lower part of the hole need to install a plug to avoid glue leakage. The designed connection type can be used when mounting the panels.

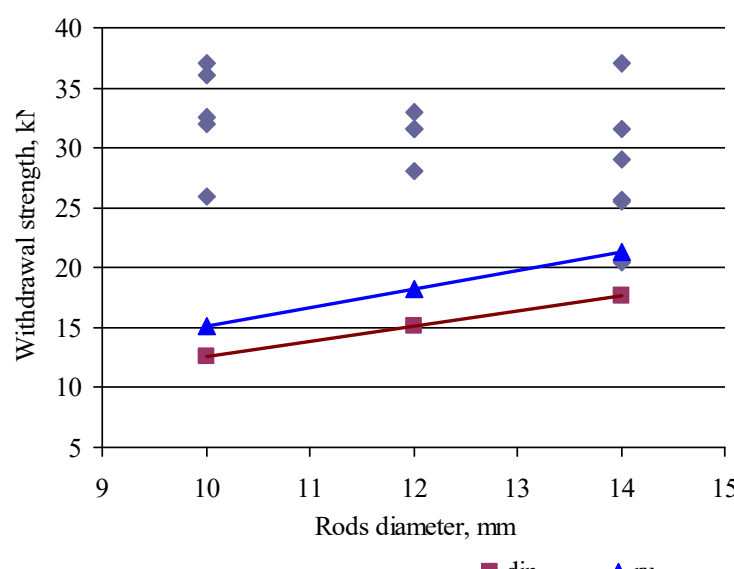

$\square \operatorname{din} \quad \Delta \mathrm{ru}$

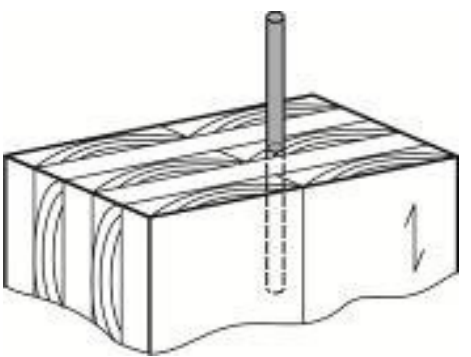

Figure 6 - Test results versus predicted strength for rods glued-in along the grain

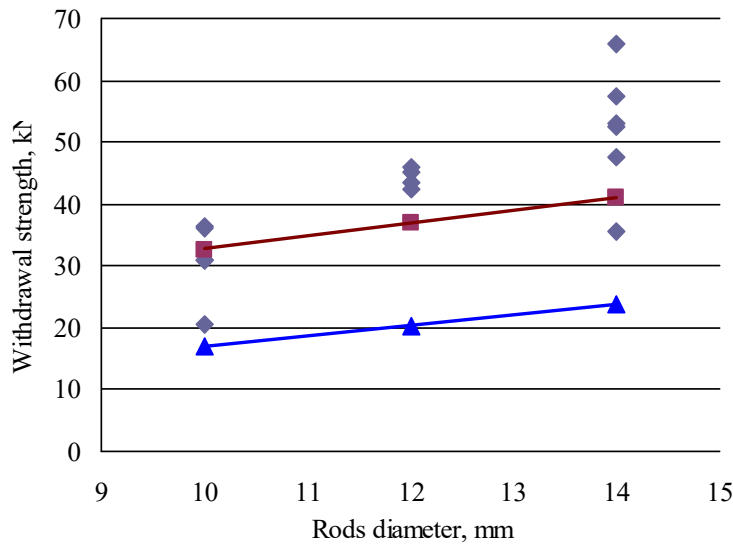

- Widmann $\Delta \mathrm{ru}$

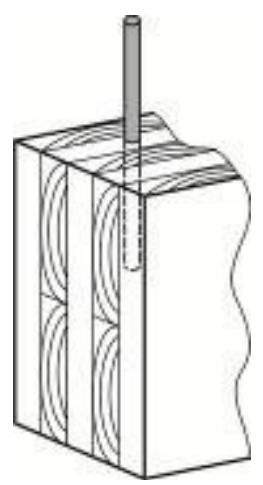

Figure 7 - Test results versus predicted strength for rods glued-in perpendicular to the grain 


\section{Conclusions}

Results of pull-pull tests glued-in steel rods positioned in the edge of CLT panels shown new and interesting results, especially for rods installed on the boundary of parallel and cross bonded boards. In described above tests series diameters of rods was smaller than thickness of boards in CLT panel. Performance of analogical tests in CLT with thin boards seems reasonable and interesting.

For future research and implementation of glued-in steel rods in CLT are need investigation of multiple rods are required for joining of thick CLT plates or highly stressed connections. In this connection, it will be necessary to determine the distances between the rods and from the rods to the edge faces, taking into account the scheme of the boards in CLT panel. Future investigations of laterally loaded glued-in steel rods in CLT are required.

Developed model of GiR strength in CLT based on the linear regression analysis of obtained test results and now it is checked by additional tests that are necessary to confirm the formulated calculation method.

\section{References}

1. Uibel, T. \& Blaß, H.J. (2007). CIB-W18/40-7-2: Edge joints with dowel type fasteners in cross laminated timber. Proceedings, CIB-W18 Meeting 2007 (Bled, Slovenia).

2. Azinović B. (2018). Glued-in rods in CLT. Short Term Scientific Mission (STSM) Report. COST Action FP1402: Basis of Structural Timber Design, 40.

3. Andersen, M. \& Høier M. (2016). Glued-in Rods in Cross Laminated Timber. Master thesis (Department of Engineering, Aarhus University, Denmark).

4. Traetta, G. (2007). Connection Techniques for CLT elements. Paper presented at the Temtis Austrian Country Seminar: Cross-Laminated Timber, Graz, Austria.

5. EN1382 (1999) Timber structures - test methods - withdrawal capacity of timber fasteners.

6. Stepinac, M., Rajcic, V., Hunger, F., van de Kuilen, J.W., Tomasi, R. \& Serrano, E. (2013). CIB-W18/46-7-10: comparison of design rules for glued-in rods and design rule proposal for implementation in European standards. Proceedings of CIB-W18 Meeting Forty-six, Vancouver, Canada.

7. Tlustochowicz, G., Serrano, E., Steiger, R. (2010). Stateof-the-art review on timber connections with glued-in steel rods. Mater. Struct., 44(5), 997-1020.

https://link.springer.com/article/10.1617/s11527-010-9682-9

8. Hunger, F., Stepinac, M., Rajcic, V., van de Kuilen, J.-W (2016). Pull-compression tests on glued-inmetric thread rods parallel to grain in glulam and laminated veneer lumber of different timber species. European Journal of Wood and Wood Products, 74, 379-391.

https://doi.org/10.1007/s00107-015-1001-2

9. Steiger, R., Gehri, E., Widmann, R. (2007). Pull-out strength of axially loaded steel rods bonded in glulam parallel to the grain. Materials and Structures, 40(1), 57-68.

10. СП 64.13330.2017 (2017). Свод правил. Деревянные конструкциии. Москва: Министерство регионального развития РФ.

11. Serrano, E. (2001). Glued-in rods for timber structures An experimental study of softening behaviour. Materials and Structures, 34, 228-234.

12. Widmann, R., Steiger, R., \& Gehri, E. (2007). Pull-out strength of axially loaded steel rods bonded in glulam perpendicular to the grain. Materials and Structures, 40(8), 827-838.
1. Uibel, T. \& Blaß, H.J. (2007). CIB-W18/40-7-2: Edge joints with dowel type fasteners in cross laminated timber. Proceedings, CIB-W18 Meeting 2007 (Bled, Slovenia).

2. Azinović B. (2018). Glued-in rods in CLT. Short Term Scientific Mission (STSM) Report. COST Action FP1402: Basis of Structural Timber Design, 40.

3. Andersen, M. \& Høier M. (2016). Glued-in Rods in Cross Laminated Timber. Master thesis (Department of Engineering, Aarhus University, Denmark).

4. Traetta, G. (2007). Connection Techniques for CLT elements. Paper presented at the Temtis Austrian Country Seminar: Cross-Laminated Timber, Graz, Austria.

5. EN1382 (1999) Timber structures - test methods - withdrawal capacity of timber fasteners.

6. Stepinac, M., Rajcic, V., Hunger, F., van de Kuilen, J.W., Tomasi, R. \& Serrano, E. (2013). CIB-W18/46-7-10: comparison of design rules for glued-in rods and design rule proposal for implementation in European standards. Proceedings of CIB-W18 Meeting Forty-six, Vancouver, Canada.

7. Tlustochowicz, G., Serrano, E., Steiger, R. (2010). Stateof-the-art review on timber connections with glued-in steel rods. Mater. Struct., 44(5), 997-1020.

https://link.springer.com/article/10.1617/s11527-010-9682-9

8. Hunger, F., Stepinac, M., Rajcic, V., van de Kuilen, J.-W. (2016). Pull-compression tests on glued-inmetric thread rods parallel to grain in glulam and laminated veneer lumber of different timber species. European Journal of Wood and Wood Products, 74, 379-391.

https://doi.org/10.1007/s00107-015-1001-2

9. Steiger, R., Gehri, E., Widmann, R. (2007). Pull-out strength of axially loaded steel rods bonded in glulam parallel to the grain. Materials and Structures, 40(1), 57-68.

10. SP 64.13330.2017 (2017). Set of rules. Timber constructions. Moscow: Ministry of Regional Development of the Russian Federation.

11. Serrano, E. (2001). Glued-in rods for timber structures An experimental study of softening behaviour. Materials and Structures, 34, 228-234.

12. Widmann, R., Steiger, R., \& Gehri, E. (2007). Pull-out strength of axially loaded steel rods bonded in glulam perpendicular to the grain. Materials and Structures, 40(8), 827-838. 